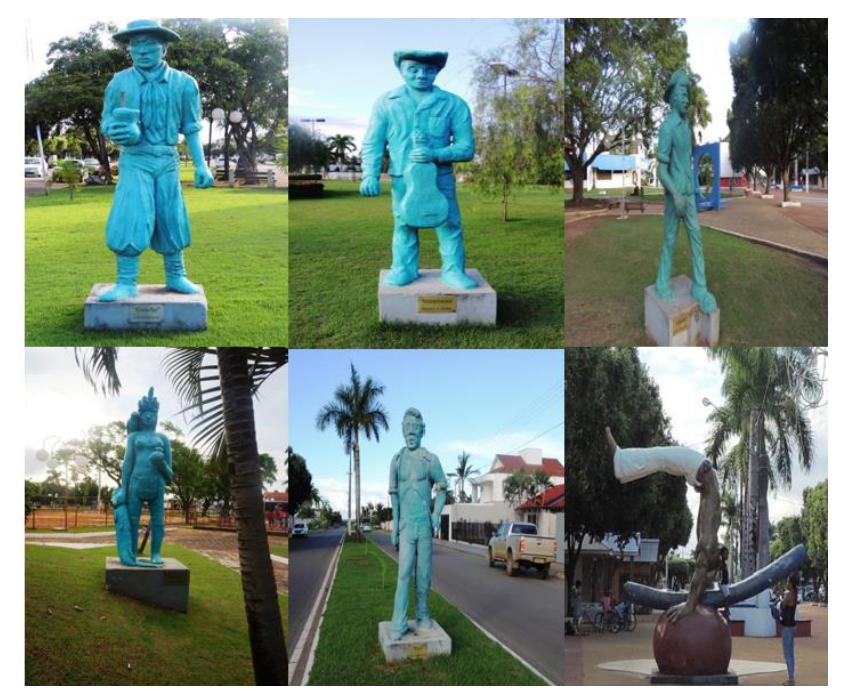

\title{
O lado nordestino da cidade de Sorriso: o lado maldito segundo a posição-sujeito sulista
}

The Northeastern side of the city of Sorriso: the wrong side according the Southern subject-position

Terezinha Ferreira de Almeida ${ }^{1}$ Maria Inês Pagliarini Cox ${ }^{2}$

Resumo: Neste estudo, propõe-se analisar dizeres que se repetem acerca da divisão do corpo social urbano de Sorriso-MT pela BR163 em lado de "cá" e lado de "lá", em lado dos sulistas e lado dos nordestinos respectivamente. O corpus, constituído por formulações recortadas de entrevista com uma moradora do lado sulista da cidade, é analisado com base nas noções de interdiscurso ou memória discursiva e posição-sujeito. Busca-se identificar e interpretar, no nível da materialidade linguística, índices evocativos de um suposto discurso segregacionista que vigora como uma espécie de senso comum entre os que vivem na cidade.

Palavras-chave: espaço urbano, discurso, segregação.

Abstract: This study analyzes recurrent sayings regarding the division of the urban social body of Sorriso, Mato Grosso, by the Highway BR163 into "this side" and "that side", that is the Southern side and the Northeastern side respectively. The corpus, constituted by formulations extracted from an interview with a resident of the Southern side of the city is analyzed based on the notions of inter-discourse or discursive memory and subject-position. The study seeks to identify and interpret, at the level of linguistic materiality, evocative indices of a supposed segregationist discourse that invigorates as a kind of common sense among the people who live in the city.

Keywords: urban space, discourse, segregation

\footnotetext{
${ }^{1}$ Professora do Instituto Federal de Educação, Ciência e Tecnologia do Mato Grosso (IFMT) Campus de Sorriso MT. terezinha.almeida@srs.ifmt.edu.br. Av. dos Universitários, 799 - Santa Clara, Sorriso - MT, 78890-000

${ }^{2}$ Professora do Programa de Pós-Graduação em Estudos de Linguagem da Universidade Federal de Mato Grosso (UFMT) e orientadora de mestrado de Terezinha Ferreira de Almeida. minescox@ hotmail.com Av. dos Universitários, 799 - Santa Clara, Sorriso - MT, 78890-000
} 


\section{Introdução}

Situado no interior do estado de Mato Grosso, o município de Sorriso é mais um dos que surgiram ao longo do traçado da BR 163. Promessa de se transformar em um importante polo agrícola desde o início de sua colonização, na década de 70 , Sorriso atraiu migrantes de várias regiões do país. De início vieram os sulistas, buscando adquirir áreas agricultáveis bem maiores do que as que possuíam em seus estados de origem, motivados pelo sonho de se tornarem "fazendeiros" e enriquecerem. Mais tarde vieram migrantes de outras regiões, principalmente do nordeste, sobretudo maranhenses, fugindo do desemprego e da garimpagem fracassada em outras áreas do estado de Mato Grosso, a exemplo de Peixoto de Azevedo. Hoje, o município, tido como próspero à luz da ideologia desenvolvimentista que presidiu a colonização da Amazônia durante o regime militar, continua atraindo pessoas de todas as regiões do estado e do país para as mais diversas atividades econômicas, vislumbrando melhores condições de vida. A convivência entre os que chegaram primeiro para colonizar a terra supostamente inabitada e os que chegaram depois, já com a cidade em pleno desenvolvimento, tem sido marcada por uma divisão que eclode na organização do espaço urbano, nas relações interpessoais, profissionais e nas práticas discursivas.

O agronegócio ganhou proporções gigantescas no município, como sinalizam os seguintes indicadores: melhor PIB agropecuário do país em 2011; status de Capital Nacional do Agronegócio em 2012; $1^{\circ}$ lugar na exportação de commodities no país em 2013. Apesar de todo esse desenvolvimento econômico, Sorriso abriga os mesmos problemas sociais de outros tantos municípios do país, apresentando uma distribuição bastante desigual da riqueza que se reflete na repartição do espaço urbano pela BR 163. Essa rodovia divide a cidade de Sorriso em duas regiões com características socioeconômicas, culturais, urbanas e demográficas bem distintas, o que faz dela uma espécie de símbolo do apartheid e da segregação reinante naquela formação social.

De um lado da BR 163, habitam os 'gaúchos', como são chamados metonimicamente os migrantes vindos da região sul (Rio Grande do Sul, Santa Catarina e Paraná), referenciados como senhores da terra, visto que são donos de quase toda a área rural do município. Como se trata de um município cuja economia é movida pela produção e comercialização de commodities agrícolas, são tidos/se têm como responsáveis pela riqueza e progresso de Sorriso. Do outro lado da BR, estão os nordestinos, metonimicamente designados como 'maranhenses'. Eles começaram a chegar ao município, na década de 1990, para empregarem-se como mão de obra não 
especializada no cultivo da terra, no trabalho doméstico, no comércio, no setor de serviços em geral, certamente não motivados pela perspectiva de enriquecimento futuro, mas desejando apenas assegurar a própria sobrevivência e a da família no presente.

As circunstâncias da migração de uns e outros são bem diferentes, como também diferentes são suas condições de habitantes do espaço urbano de Sorriso. Os pioneiros recebiam, gratuitamente, lotes na sede do município, ao comprarem terras nas áreas rurais; os outros, muitos deles, sequer tinham meios de pagar um aluguel (inflacionado pela lei da oferta e da procura). Por isso, engrossavam/engrossam a população urbana dos sem teto, disposta a ocupar áreas desocupadas próximas à cidade, sobremaneira aquelas aprioristicamente destinadas ao parque industrial. Destarte, desde o princípio, são vistos como sinônimo de desordem e problema social para o município. Em torno deles se avoluma um discurso segregacionista, metaforizado pelos dêiticos "cá" e "lá" que, agenciados discursivamente, assim significam: "cá" (= o centro da cidade, o lugar dos migrantes colonizadores sulistas, também chamados de "gaúchos") e "lá" (= a periferia, o lugar dos migrantes nordestinos, também chamados de "maranhenses"). Enfim, os dêiticos "cá" e "lá" não significam apenas o lugar próximo ou distante do enunciador, mas carreiam os sentidos da divisão do corpo social urbano de Sorriso historicamente constituídos.

De acordo com Orlandi (2012, p.199), “o modo como se dispõe o espaço é uma maneira de configurar sujeitos em suas relações, em suma, de significá-los”. Nesse sentido, a divisão entre o "cá" e o "lá" revela como nele se dão e são significadas as relações sociais na cidade de Sorriso. No "cá", a metade "gaúcha" da cidade, desenvolvimento, organização e planejamento urbano, saneamento básico, câmeras de segurança, centro comercial, construções a partir de projetos arquitetônicos arrojados, casas construídas em terrenos amplos com jardins e piscinas, avenidas largas, praças, áreas verdes mostram a presença efetiva do poder público municipal na gestão do espaço, bem como o alto poder aquisitivo de seus moradores. No "lá", a metade "maranhense" da cidade, bairros com infraestrutura precária ou sem infraestrutura, escondidos atrás de armazéns e silos do parque industrial, frutos de ocupação geralmente desordenada, motivada por invasões de terrenos, transporte ineficiente, ruas estreitas, casas humildemente construídas sem projeto arquitetônico, próximas umas das outras e margeando as ruas, ausência de espaços de lazer mostram o descaso do poder público, bem como o baixo poder aquisitivo de seus moradores. 
Este artigo baseia-se na dissertação $A$ BR 163 no município de Sorriso: apartheid do corpo social urbano ${ }^{3}$ que teve por objetivo apreender os efeitos de sentido que recobrem o lado maranhense ou nordestino da cidade no discurso/ideologia da colonização sulista em circulação no norte de Mato Grosso desde a década de 1970. Aqui vamos examinar apenas um dos oito objetos discursivos - quatro matérias midiáticas e quatro entrevistas - dos quais se recortaram as redes de formulações que compõem o corpus analisado na dissertação. Trata-se de recortes de uma entrevista realizada pela pesquisadora Luciana Schleder Almeida para a tese Gaúchos, festas e negócios: o agronegócio da soja no meio-norte mato-grossense ${ }^{4}$. Na entrevista, a pesquisadora conversa com um casal gaúcho que habitava o lado de "cá" de Sorriso. Num dos momentos da conversa, a esposa expressa incisivamente seu estranhamento “O povo desse lado ali é o povo mais nordestino. A maioria é nordestino. É incrível de ver, quando eu passo ali, nem parece que a gente tá em Sorriso." - ante ao modo de vida do 'lado de lá' da cidade, por onde obrigatoriamente tinham de passar para chegar ao clube de que eram sócios. O desafeto pela gente do lado de lá é tal que a leva a desistir de frequentar o clube. Assim, partindo do pressuposto de que a vida cotidiana no espaço urbano de Sorriso é presidida por um discurso segregacionista, buscamos identificar e interpretar, no nível da materialidade linguística, o que ratifica a relação dos enunciados atuais (a formulação), recortados da referida entrevista, com o interdiscurso ou a memória discursiva (a constituição), no tocante à discriminação de nordestinos por sulistas na cidade. Pretendemos, por meio dessa démarche, compreender como se (re)produzem os sentidos da divisão, hierarquização, discriminação e segregação, e não os sentidos da complementariedade e da igualdade entre os sulistas e os outros na sociedade sorrisense.

\footnotetext{
${ }^{3}$ A dissertação A BR 163 no município de Sorriso: apartheid do corpo social urbano foi defendida por Terezinha Ferreira de Almeida junto ao Programa de Pós-Graduação em Estudos de Linguagem da Universidade Federal de Mato Grosso, em fevereiro de 2016. Examinando o imaginário e a memória discursiva da sociedade sorrisense, a dissertação teve por objetivo captar os sentidos que recobrem a divisão geográfica da cidade pela BR 163 que, apesar de ligar o município com o sul e o norte do estado e do país, no perímetro urbano, atua como um muro que divide o corpo social em dois grupos. Não é, pois, como referente físico que a BR 163 interessa a esta pesquisa e sim como referente discursivo. Interposta entre o "cá" e o "lá", a rodovia funciona como uma metáfora da divisão interna do corpo social de Sorriso, como um símbolo do apartheid silencioso que vige entre sulistas e não-sulistas. Ecos da memória discursiva que afasta o "cá" (o lado dos sulistas) e o "lá" (o lado dos não-sulistas) podem ser ouvidos frequentemente em variadas cenas de enunciação.

${ }^{4}$ A tese Gaúchos, festas e negócios: o agronegócio da soja no meio-norte mato-grossense foi defendida por Luciana Schleder Almeida junto ao Programa de Pós-Graduação em Sociologia e Antropologia da Universidade Federal do Rio de Janeiro em 2013. Teve como objeto de estudo as formas de sociabilidade entre produtores agrícolas.
} 


\section{Discurso e noções correlatas}

Inscrevemo-nos no campo da Análise do Discurso, desenvolvida sob o signo das ideias de Michel Pêcheux (1969; 1975), pautando nossa leitura do conjunto de formulações pelas noções de discurso, formação discursiva, interdiscurso e intradiscurso e forma-sujeito, tal como lidas pela linguista Eni Orlandi (2012, 2008, 2004, 1999 e 1998), referência brasileira nessa vertente teórica. Sem delonga, recordemos a vocação da análise de discurso que é a de compreender "como um objeto simbólico produz sentidos, como ele está investido de significância para e por sujeitos.” (ORLANDI, 1999, p. 26).

Nessa perspectiva teórica, os discursos não são autônomos e homogêneos e nem criação de um sujeito. Ao nascermos, afirma Orlandi (1999, p. 35), “os discursos já estão em processo e nós é que entramos nesse processo. Eles não se originam em nós. Isso não significa que não haja singularidade na maneira como a língua e a história nos afetam. Mas não somos o início delas". Para a autora, os discursos, e não as palavras em estado de léxico, ou seja, de sistema, são os sítios dos sentidos por meio de que significamos o mundo. Os sentidos se constituem nos discursos que, por sua vez, se remetem a formações discursivas, como instâncias práticas de formações ideológicas características de uma dada formação social. Assim, formação discursiva, formação ideológica e formação social encontram-se estreitamente ligadas na esfera da análise de discurso, como podemos atestar na seguinte definição: “A formação discursiva se define como aquilo que numa formação ideológica dada - ou seja, a partir de uma posição dada em uma conjuntura sócio-histórica dada - determina o que pode e deve ser dito" (ORLANDI, 1999, p. 43). À luz dessa noção, somos levados a considerar que há uma relação inextricável entre sentido, sujeito e ideologia.

Se, num primeiro momento da análise de discurso, uma formação discursiva era pensada como um domínio autônomo em relação ao conjunto das formações discursivas coexistentes, não tardou a ser vista como "uma regionalização do interdiscurso, como uma configuração específica dos discursos em suas relações" (ORLANDI, 1999, p. 43). Lembra-nos Maldidier (2003, p. 51) que, embora o embrião da noção de interdiscurso já estivesse presente nos primeiros escritos de Pêcheux, mais precisamente na Analyse automatique du discours (1969), na postulação da "hipótese da relação do discurso ao ‘já dito', ‘já ouvido”, foi apenas na obra Les Vérités de la Palice (1975) que o autor consolidou o uso do termo interdiscurso para designar o "todo complexo com dominante das formações discursivas intrincado no complexo das formações 
ideológicas" (PÊCHEUX, [1975] 1988, p. 146). Para Maldidier (2003, p. 51), “o interdiscurso designa o espaço discursivo e ideológico no qual se desdobram as formações discursivas em função das relações de dominação, subordinação, contradição", coroando a abóboda do construto teórico arquitetado por Michel Pêcheux.

E, paralelamente à noção de interdiscurso, Pêcheux ([1975] 1988, p. 167) propõe a noção de intradiscurso, tido como "o fio de discurso" atribuído a um sujeito. Ainda que, nessa posição, o sujeito se imagine/se porte como a fonte do que diz/significa, ele é sempre atravessado pelo interdiscurso. Assim, o intradiscurso é o lugar em que a formasujeito tende a absorver-esquecer a presença constitutiva do interdiscurso: "A formasujeito do discurso, na qual coexistem, indissociavelmente, interpelação, identificação e produção de sentido, realiza o 'nonsense' da produção do sujeito como 'causa de si' sob a forma de evidência primeira" (PÊCHEUX, [1975] 1988, p. 295). Em resumo, no intradiscurso, o sujeito $a$ é levado a funcionar como um sujeito de, graças à obliteração das causas que o determinam.

As noções de interdiscurso e memória discursiva se recobrem, se concebermos a última como "o saber discursivo que torna possível todo dizer e que retorna sob a forma do pré-construído, o já dito que está na base do dizível, sustentando cada tomada da palavra" (ORLANDI, 1999, p. 31). Ao articular essas duas noções, a autora busca realçar a historicidade do sentido e a impossibilidade de um sujeito inventar o próprio verbo. Orlandi (1999, p. 32) afirma que as “ palavras não são só nossas. Elas significam pela história e pela língua. O que é dito em outro lugar também significa em nossas palavras. O sujeito diz, pensa que sabe o que diz, mas não tem acesso ou controle sobre o modo pelo qual os sentidos se constituem nele."

$\mathrm{Na}$ retomada que faz das noções de interdiscurso e intradiscurso, Orlandi (1999), dialogando com Courtine ([1984] 2009), fala delas em termos de constituição e formulação respectivamente. O interdiscurso, como eixo da constituição dos discursos, funciona verticalmente, disponibilizando "todos os dizeres já ditos - e esquecidos - em uma estratificação de enunciados que, em seu conjunto, representa o dizível" (ORLANDI, 1999, p. 32 e 33). Já o intradiscurso, como eixo da formulação, funciona horizontalmente, possibilitando a atualização dos dizeres em momentos e condições específicas. É o interdiscurso que "governa a repetibilidade no seio de uma rede de formulações" (COURTINE, [1984] 2009, p. 100).

A memória discursiva é, pois, entendida como saberes anteriormente constituídos que viabilizam a produção de sentidos. Desse modo, ela atualiza as 
possibilidades do dizer no momento da enunciação, em um processo histórico resultante de uma disputa de interpretações para acontecimentos presentes ou já ocorridos. A memória se configura, assim, pelo atravessamento de discursos, pela relação que os discursos mantêm entre si, em constante errância e movimento, imbricando-se e confundindo-se. Afirma Orlandi (1999, p. 33 e 34) que, "para que as minhas palavras tenham sentido é preciso que elas já façam sentido", sendo necessário, para isso, que o que foi dito por alguém, num momento particular, seja esquecido e passe para o anonimato. Em outros termos, "todo discurso se delineia na relação com outros: dizeres presentes e dizeres que se alojam na memória" (ORLANDI, 1999, p. 43).

Passando para o anonimato, as palavras do outro são ditas, no nível do intradiscurso e da formulação, como se originárias dos sujeitos que as dizem, mesmo não sendo. Isso ocorre porque "a subordinação-assujeitamento se realiza sob a forma da autonomia, como interior sem exterior, esfumando-se a determinação do real (do interdiscurso), pelo modo mesmo com que ele funciona" (ORLANDI, 1999, p. 47).

Se, sob o signo do materialismo, o sujeito do discurso se torna sujeito ao discurso e à ideologia, sob aquele da psicanálise, passa a ser visto como clivado, cindido e descentrado. Atravessado pela ideologia e pelo inconsciente, o sujeito, suscetível a falhas pela sua clivagem, repete discursos já efetivos, mas o faz alimentado pela ilusão de ser a fonte do que diz, pois, a ideologia jurídica, dominante na modernidade, o significa como livre, consciente e independente de qualquer determinação.

A forma-sujeito que, na postulação de Althusser (1985), é constituída pelas ideologias engendradas sob o signo da ordem antropocêntrica, sobre a qual se erigiram, na idade moderna, o direito, a filosofia idealista, a estética romântica, a ética, a economia e a política neoliberal, o capitalismo, a psicologia, a pragmática, dentre tantos outros saberes e práticas que regem a vida do homem, figura como um sujeito responsável pelo que diz, como um sujeito soberano, autônomo e criativo para dizer o que pensa/deseja, como um sujeito que se auto-governa e controla seu dizer, como um sujeito racional que sabe o que diz, como um sujeito uno, homogêneo e coerente. Absorvido por essa ordem de discurso, o sujeito tem sua visão toldada, pensa-se como causa e não como efeito daquilo que o determina.

Contudo, para fazer sentido, esse sujeito, qualquer sujeito, não pode não se abismar no outro, não pode não fazer ecoar os sentidos que povoam a memória discursiva. Diz propriamente Pêcheux ([1975] 1988, p. 153), "Como se eu que falo 
estivesse no lugar onde alguém me escuta". Nos termos de Cox (1989, p. 139), "sob a máscara do 'eu falo', vive o Outro a me fazer falar sem que eu queira/saiba/fale. Atrás do palco onde o sujeito diz 'eu falo', age ininterruptamente o processo de interpelação ideológica e discursiva”. Nenhum outro enunciado reflete tão propriamente a ideia do sujeito cindido quanto aquele de Rimbaud (1972, p. 248) “C'est faux de dire Je pense: on devrait dire on me pense - pardon du jeu de mot. Je est un autre." 5 Nesse enunciado a quebra sintática entre je e est (ou seja, a não concordância verbal entre o sujeito pronominal je e o predicado est un autre) é a expressão material de uma desconstrução violenta do cogito cartesiano que leva a uma afirmação paradoxal: a identidade é a alteridade. Na oração on me pense, o sujeito/agente je se transforma em objeto/paciente me. O sujeito é o on, um pronome indefinido, que evoca "uma força anônima que escapa à condição de pessoa, quer seja o texto do inconsciente, a linguagem, o corpo social do discurso, o texto da cultura, que me fala, que fala através de mim" (FELMAN, 1978, p. 104). Trazido para a Análise de discurso, esse on seria o equivalente do inconsciente e das formações discursivo-ideológicas que interpelam o indivíduo em sujeito.

Para dar conta da contradição vivida pelo sujeito entre ser determinado pelas formações discursivo-ideológicas (ser sujeito $a$ ) e ter a ilusão de ser a fonte do sentido (ser sujeito de), Pêcheux ([1975] 1988, p. 173-185) propõe a noção de esquecimento $\mathrm{n}^{\text {o }}$. 1 e $n^{\circ} .2$. O esquecimento não deve ser entendido como perda de algo sabido, mas como acobertamento da causa do sujeito no próprio interior de seu efeito. $\mathrm{O}$ esquecimento $\mathrm{n}^{\circ}$. 1 é de ordem ideológica, já o esquecimento $\mathrm{n}^{\circ} .2$ é de ordem enunciativa. Pelo esquecimento $\mathrm{n}^{\circ}$. 1, temos a ilusão de ser a fonte dos nossos enunciados e produtores de sentidos, quando na verdade, só fazemos repetir sentidos já existentes. Pelo esquecimento $n^{\circ}$. 2, somos tomados por uma ilusão referencial que “produz em nós a impressão da realidade do pensamento [...] e nos faz acreditar que há uma relação direta entre o pensamento, a linguagem e o mundo, de tal modo que pensamos que o que dizemos só pode ser dito com aquelas palavras e não outras, que só pode ser assim." (ORLANDI, 1999, p.35). Lembra-nos Orlandi (1999, p. 36) que "As ilusões não são 'defeitos', são uma necessidade para que a linguagem funcione nos sujeitos e na produção de sentidos”.

\footnotetext{
5 “É falso dizer Eu penso: deveríamos dizer pensam-me - perdão pelo jogo de palavras. Eu é um outro". (RIMBAUD, 1972, p. 248).
} 
Essas considerações desembocam na compreensão de que, discursivamente, o sujeito funciona como uma posição, um lugar a ser ocupado. Não importa o sujeito empírico que ocupe uma dada posição, o sujeito discursivo será o mesmo. Por isso se diz, em análise de discurso, que "os sujeitos são intercambiáveis" (ORLANDI, 1999, p. 49). Segundo Foucault ([1969] 1986, p. 142), "Não importa quem fala, mas o que ele diz não é dito de qualquer lugar. É considerado, necessariamente, no jogo de uma exterioridade", referindo-se o termo exterioridade ao complexo de formações discursivas, ou seja, ao interdiscurso. Orlandi distingue a situação (domínio empírico) da posição (domínio discursivo), afirmando que é a posição, e não a situação, que significa no discurso. Para ela, as posições "significam em relação ao contexto sóciohistórico e à memória (o saber discursivo, o já-dito)" (ORLANDI, 1999, p. 40). E as palavras significam de acordo com as posições daqueles que as enunciam e mudam de sentido quando mudam de posição, como lemos na primeira tese de Pêcheux ([1975] 1988, p. 160):

As palavras, expressões, proposições, etc., mudam de sentido segundo as posições sustentadas por aqueles que as empregam, o que quer dizer que elas adquirem seu sentido em referência a essas posições, isto é, em referência às formações ideológicas [...] nas quais essas posições se inscrevem. Chamaremos, então, formação discursiva aquilo que, numa formação ideológica dada, isto é, a partir de uma posição dada numa conjuntura dada, determinada pelo estado da luta de classes, determina o que pode e deve ser dito (articulado sob a forma de uma arenga, de um sermão, de um panfleto, de uma exposição, de um programa, etc.). (grifos do autor)

É, pois, com base em tais noções que esboçamos o presente estudo. Todavia, antes de procedermos à análise, revisitamos a discussão realizada por Orlandi (2004; 2012) sobre a cidade como espaço simbólico, fazendo um contraponto com noções propostas por Lefebvre $(1999 ; 2000)$ acerca do pensamento do urbano.

\section{A cidade como espaço simbólico}

A cidade "se materializa em um espaço que é um espaço significativo: nela, sujeitos, práticas sociais, relações entre o indivíduo e a sociedade têm uma forma material, resultante da simbolização da relação do espaço, citadino, com os sujeitos que nela existem, transitam, habitam, politicamente significados" (ORLANDI, 2012, p. 200). Em seus estudos sobre o discurso urbano, a autora define duas noções: ordem e 
organização urbana. A ordem corresponde ao real da cidade, a seus movimentos e à sua forma histórica, já a organização urbana está atrelada ao planejamento que é feito desse espaço por administradores e urbanistas de acordo com seus objetivos e ao imaginário projetado pelos habitantes sobre a cidade (ORLANDI, 2012, p.199). Enquanto os especialistas do espaço se voltam para organização da cidade, os analistas de discurso focalizam sua ordem, sua dimensão simbólica, o modo como a cidade significa as relações sociais que nela se desenrolam. Ao passar da ordem para a organização, passase do discurso $d a$ cidade para o discurso sobre a cidade. E, segundo Orlandi (2004, p. 34), o discurso sobre o urbano tende a silenciar o discurso urbano, o "real da cidade (e o social que o acompanha)".

Podemos relacionar essa distinção entre discurso da cidade e discurso sobre a cidade com a distinção que Lefebvre (2000) faz acerca da prática espacial ou espaço vivido e representação do espaço ou espaço concebido.

A prática espacial refere-se à interação entre as ações humanas e os suportes materiais do espaço, assegurando a sua reprodução. Toda sociedade produz lentamente seu espaço, dominando-o e se apropriando dele. O que caracteriza a prática espacial nas sociedades urbanas contemporâneas? É a articulação entre a realidade cotidiana (o emprego do tempo) e a realidade urbana (o percurso, as redes ligando os lugares de trabalho, da vida privada, da vida pública, do lazer). Paradoxalmente, a prática espacial ou espaço vivido inclui a separação entre os lugares que religa.

Já as representações do espaço constituem os discursos produzidos por intelectuais, planejadores, urbanistas, tecnocratas e outros profissionais da esfera pública ou privada que buscam a conformação do vivido ao concebido. Tais representações tenderão para um sistema de signos verbais ou visuais elaborados intelectualmente, mediante os quais se procede à análise dos espaços tanto quanto das sociedades que os produziram e neles se estabeleceram. Nos termos de Duarte (2002, p. 75), as representações produzem um meta-espaço, um espaço abstrato que substitui a "heterogeneidade da forma urbana (valor de uso) pela homogeneidade do espaçomercadoria, da equivalência abstrata entre os diferentes (valor de troca)".

Não raro, na história das cidades, as práticas espaciais entram em conflito com as representações do espaço. No caso das cidades modernas, formadas a partir de uma concepção ou representação prévia, nem tudo sai de acordo com o planejado. Por exemplo, em Sorriso, que é o objeto deste estudo, o projeto urbano concebia a setorização funcional do espaço, tendo como limite a BR 163 que deveria separar o lado 
que abrigaria o parque industrial da cidade do lado que abrigaria o centro comercial, a administração, os bairros residenciais e os serviços de que a população necessita cotidianamente. Contudo, a prática espacial, num determinado momento da história de Sorriso, fugiu ao script do projeto de urbanização: migrantes pobres, principalmente exgarimpeiros, que chegavam à cidade na década de 1990, sem lugar para se instalar na área residencial, começaram a tomar posse de áreas vazias no lado industrial da cidade e erguer barracos onde pudessem se abrigar. Em pouco tempo, o que era para ser o parque industrial se tornou uma área residencial popular que não cessa de se expandir. Muito comumente o espaço concebido é incapaz de conter a potência da prática espacial que parece ter vida própria, a ponto de provocar a explosão de toda sorte de planejamento.

Contudo, nem sempre a direção da interferência é da prática espacial sobre o espaço concebido. Pode ocorrer o inverso por meio do processo de "gentrificação" de áreas urbanas muito importantes no passado (centro histórico, regiões portuárias, ferroviárias etc.), mas que, com o crescimento da cidade, se degradaram e passaram a abrigar uma população de pessoas empobrecidas e marginalizadas socioeconômica e culturalmente. Gentrificar significa, pois, enobrecer uma área desvalorizada de acordo com projetos de revitalização do espaço urbano, via de regra, envolvendo iniciativa público-privada. Tudo começa com uma representação do espaço que define as transformações urbanas a serem realizadas. Vale lembrar que as melhorias das áreas revitalizadas nunca são desfrutadas pelos seus antigos moradores, já que eles terão sido “despejados" e "depositados" nos bairros populares da periferia da cidade. Não há unanimidade na visão dos urbanistas com relação a essa prática: para uns, ela é a solução para regenerar áreas deterioradas, mas, para outros, trata-se de uma prática higienista que busca transformar áreas centrais degradadas e conflituosas em espaços destinados ao entretenimento e ao consumo para uma parcela da população com perfil socioeconômico superior. A gentrificação atua no sentido inverso ao ideal democrático da polis, que é o de convívio e interação das diferenças sociais e culturais. O exemplo mais conhecido de "revitalização" no Brasil é o do Pelourinho em Salvador, realizado na década 1990. Por meio dele, se desalojaram os antigos moradores dos casarões coloniais do centro histórico e se promoveu uma operação de restauração das fachadas dos edifícios e de renovação e readequação de seu interior para a instalação de restaurantes, lojinhas de artesanato, escolas, museus, espaços para show e apresentações artísticas, instituições várias etc., voltados diretamente para os turistas. 
Segundo Lefebvre (1999, p. 110), o espaço urbano é uma força centrípeta, uma "centralidade" que reúne todas as diferenças, mas é também uma força centrífuga que gera a "policentralidade", a saber, "a disseminação e a constituição de centros diferentes, seja para a dispersão, seja para a segregação”. Para lidar com a noção paradoxal do espaço urbano como espaço que, ao mesmo tempo, reúne e separa, Lefebvre distingue diferença e distinção de separação e segregação. Para ele, a diferença implica relação, proximidade, encontro, informação, ao passo que a segregação implica a ruptura da relação, dificultando a aproximação e o encontro dos diferentes.

Com base nessas noções, podemos pensar em Sorriso, pelo seu vigor econômico, como uma força centrípeta que atrai levas de migrantes imbuídos do sonho de melhorar de vida. Nesse sentido, a cidade é uma centralidade que atrai e congrega as diferenças. Contudo, percebemos também a atuação de uma força centrífuga que age no sentido de afastar os migrantes não-sulistas - os outros - dos migrantes sulistas, impedindo que eles se instalem do mesmo lado da BR163 - o lado de "cá" - e se tornem seus vizinhos próximos. Essa força centrífuga, que repele os não-sulistas e os leva a se assentarem do lado de "lá" da BR, gera uma policentralidade que os confina e segrega em um espaço urbano outro que não o dos sulistas.

A separação e a segregação, consoante Lefebvre, são próprias de uma ordem totalitária que nega a lógica do urbano - a lógica da concentração e da centralidade. Se é a centralidade que caracteriza o urbano, então o modelo da racionalidade industrial (que separa/discrimina/classifica/distribui) é inadequado para o exercício de pensá-lo e representá-lo. Para se aproximar do urbano, o pensamento não pode separar, segregar e descartar nada, precisa juntar tudo o que foi, historicamente, separado; não pode mais imitar a empresa ou a indústria, mas a própria forma urbana que, como prática espacial, reúne e promove o encontro das diferenças. Enfim, o pensamento do urbano precisa se desatrelar da racionalidade industrial, que é discriminatória e classificatória, e passar a imitar a racionalidade urbana, que é acumulativa, uma forma de racionalidade cuja origem, segundo Lefebvre (1999), é prenunciada já no gesto ancestral dos coletores, gesto de reunião de coisas.

De acordo com Lefebvre (1999, p. 42-48 e 115-124), o espaço urbano é, pois, um espaço diferencial. E, para esmiuçar o conceito de espaço diferencial, o autor recorre aos conceitos de isotopia e heterotopia. Pelo conceito de isotopia, o autor se refere à ordem próxima, àquilo que faz de um lugar (-topia) um lugar do mesmo (iso-), um lugar 
de homologias. Para se chegar às isotopias, transformam-se diferenças contíguas em separação e segregação urbana, para evitar que elas se encontrem no mesmo espaço. Nada ilustra tão bem o princípio isotópico quanto os condomínios fechados que reúnem os iguais e, concretamente, os apartam dos diferentes. Também são exemplos de isotopia os conjuntos habitacionais populares, geralmente plantados em áreas consideradas menos nobres do ponto de vista do capital imobiliário-financeiro. Já, pelo conceito de heterotopia, o autor se refere à ordem distante, àquilo que faz de um lugar (topia) o lugar do outro (hetero-), ao mesmo tempo excluído e incluído. Quando se pensa no espaço urbano de modo global, é impossível não vê-lo como uma acumulação de heterotopias. As cidades são profundamente heteretópicas, mas as políticas públicas em cumplicidade com a iniciativa privada não se afastam do propósito de torná-las isotópicas.

É preciso lembrar ainda que isotopia e heterotopia não são categorias estanques. Um espaço aparentemente isotópico, como o das imediações de um shopping de luxo, pode se tornar altamente heterotópico, ao atrair uma numerosa população de indesejáveis (vendedores ambulantes, flanelinhas, mendigos, artistas de rua, drogaditos e uma série de outras pessoas marginalizadas) que frequentam o local não como potenciais consumidores, mas como proscritos da sociedade de consumo. Na heterotopia, sempre há o contraste que pode gerar o conflito. Porém, a violência costuma irromper quando o discurso sobre o urbano (o espaço concebido), ignorando a ordem do urbano (a prática espacial), que é uma ordem conflitual, deseja converter espaços heteretópicos em espaços isotópicos ou, vice-e-versa, quando a ordem do urbano (a prática espacial), que é heterotópica, estilhaça o que a organização (o espaço concebido) havia tornado isotópico. Como exemplo do primeiro caso, pode-se citar a resistência dos despejados de uma área a ser gentrificada e, do segundo, a invasão de um imóvel desocupado em área nobre de uma metrópole por pessoas desabrigadas. Nos dois casos, a ordem conflitual reinante na cidade costuma desembocar na violência, contida, comumente, pela força e repressão policial.

A forma como o espaço urbano é organizado e distribuído indicia modos de significar as relações entre os sujeitos que nele vivem. Consoante Orlandi (2012),

[...] a cidade é um espaço significante, investido de sentidos e sujeitos, produzidos em uma memória. Quando se fazem certos gestos em relação a essa memória - são gestos de interpretação dela - se está transformando, modificando, ou não esta memória. E isto traz consequências para o espaço e para seus habitantes (ORLANDI, 2012, p.205). 
Por exemplo, na memória de quem vive na cidade, ruas são espaços públicos, espaços interpretados como livres à circulação de quem quer que seja, espaços potencialmente heteretópicos. Assim, quando se fecha uma rua com cerca e cancela e se planta um guarda para vigiá-la 24 horas por dia, com poder de decidir quem pode e quem não pode circular por ela, modifica-se a memória que se tinha da cidade. Trata-se, pois, de um gesto de violência simbólica que afeta a relação do cidadão com o urbano: os que se encontram do lado de fora do muro são tomados indistintamente como indesejáveis, tendo sua circulação regulada nesses espaços. Conforme Orlandi (2004, p. 49): "Se a cidade é o lugar da interpretação com sua particularidade significativa, a rua é estruturante no imaginário em que a cidade significa: via pública, calçadas, passantes. Lugar do público, lugar comum". A prática de condominializar ruas em nome da segurança dos moradores, muito em moda em bairros de classe média alta ou alta, implica, pois, uma divisão e uma mudança no modo de significar os cidadãos: ela separa sujeitos que ficam pelo lado de dentro dos sujeitos que ficam do lado de fora. Quem está dentro da cidadela é visto como socius (os iguais), ao passo que quem está do lado de fora é visto como hostis (os inimigos). O gesto de fechar/murar um bolsão de residências modifica, segundo Orlandi (2004, p. 84), “as condições de produção de sentido em sua materialidade". Diz a autora:

Por esse gesto, fica "dito" que os que estão do lado de lá do muro são as pessoas com as quais se quer conviver, quem está para fora são as que se excluiu. O social fica indistinto porque não são todos que estão do lado de fora que são nossos 'inimigos'. Então o 'hostis' (inimigos) e o socius (nossos iguais) ficam confundidos. [...] Ao se fechar um bolsão, se está fazendo uma violência social que é separar sujeitos de sujeitos igualmente cidadãos, mas que se passa a tratar como se fossem uma ameaça. Há grave diminuição do espaço de sociabilidade. Nesse imaginário, eficaz, acabam-se implementando hostilidades que fazem as pessoas se 'estranharem'. (ORLANDI, 2004, p. 84).

Essa divisão do corpo social urbano em socius e hostis, certamente motivada pelo princípio da isotopia, reduz o espaço de sociabilidade que pode resultar em mais hostilidade e violência, quer dizer, produzir um efeito contrário ao que se deseja com a condominialização - a segurança. A demasiada preocupação com a segurança é reflexo da inversão da forma como o Estado administra os problemas sociais que espocam na cidade, controlando seus efeitos por meio da repressão, sem tratar as causas. 
A mão da organização urbana produz uma "verticalização das relações horizontais na cidade, que, de espaço material contíguo, se transforma em espaço social hierarquizado (vertical)" (ORLANDI, 2004, p. 35). Essa verticalização reparte o território em regiões e estabelece fronteiras, dificultando ou mesmo impedindo "a convivialidade, o trânsito horizontal entre vizinhos" (ORLANDI, 2008, p. 189). Privilegia-se o convívio dos iguais; interdita-se o encontro dos diferentes. A homogeneização e hierarquização, garantidas pela organização urbana, buscam silenciar os conflitos estruturantes da ordem urbana, mas, não raro, podem gerar a violência. Segundo Orlandi (2008, p. 191), o conflito, dada a concentração de diferenças no espaço urbano, é inerente à cidade, mas não a violência que "se produz pelas condições de vida social, é mantida por políticas apenas repressivas e não formadoras da sociabilidade e desencadeadas por soluções imediatistas”. Orlandi (2012, p.212) afirma ainda que "quanto mais dentro do social, mais seguros estamos".

Nem sempre o que segrega tem a concretude de um muro, como aqueles que apartam as cidadelas condominializadas do resto do corpo social urbano, ou como aquele que separava a Berlim Oriental da Berlim Ocidental, ou como as cercas com arame farpado e concertina que alguns países europeus estão instalando em suas fronteiras para impedir a entrada de refugiados políticos vindos de diversas regiões do Oriente Médio e África, ou como as muralhas que separam o território palestino da Faixa de Gaza do Egito e Israel, dentre outros. Às vezes, a barreira que separa é muito mais tênue do que um muro. Pode ser, por exemplo, a divisão entre centro e periferia, zona norte e zona sul, morro e orla, favela e bairro, os limites de um bairro, uma avenida ou uma rua etc. Há regiões malditas, há bairros malditos e há ruas malditas em torno de que se avoluma uma prática discursiva que fomenta a segregação, gerando "no ambiente da cidade, uma relação tensa entre o socius e o hostis". (MARTINS, 2012, p. 40 e 41). Nessa prática discursiva, comumente, os hostis são significados como aqueles que não se quer por perto, aqueles com os quais não se quer encontrar de forma alguma. São demonizados, avaliados negativamente, discriminados, associados à marginalidade, criminalidade, tráfico, vício, vadiagem, pobreza, ignorância, preguiça etc. Enfim, por meio de muros concretos e/ou simbólicos, institui-se um apartheid entre os socius e os hostis.

Não é outro o caso da cidade de Sorriso, dividida pela BR163, em lado de "cá" (o lado do migrante sulista) e lado de "lá" (o lado do migrante nordestino). Quem vive na Sorriso do lado de "cá" sabe o quão fecunda é a prática discursiva que demoniza o 
corpo social urbano da Sorriso do lado de "lá", tanto no burburinho cotidiano das ruas quanto na esfera política, policial, midiática, dentre outras. A BR 163 não opera apenas uma divisão geográfica de Sorriso, mas estabelece um apartheid do corpo social urbano, que separa horizontal e, também, verticalmente os migrantes que chegaram primeiro, na condição de colonizadores e pioneiros, daqueles que chegaram depois, na condição de desempregados literalmente "sem eira e nem beira" (sem terra e sem casa). A separação espacial entre "cá" e "lá" pela BR 163 vale, pois, como uma metáfora da separação social, econômica, étnica e de sentidos vigente na sociedade de Sorriso. E são, pois, os processos de produção de sentidos que, na formação social de Sorriso, transformam a diferença e a distinção entre nordestinos ou maranhenses e sulistas ou gaúchos em separação e segregação espacial que tomamos como objeto deste estudo.

\section{O lado de "lá": "quando eu passo ali, nem parece que a gente tá em Sorriso".}

Em nossa análise, vamos destacar aqueles elementos materiais que, na formulação $(\mathrm{F})^{6}$, indiciam a relação do intradiscurso, ou seja, da entrevista aqui analisada, com o interdiscurso, a memória discursiva, à guisa de constituição dos sentidos. Ponderamos, com Sériot (1986, p. 14), que "si l'on considère, en effet, la syntaxe comme un système neutre et clos, comment alors admettre qu'un texte peut porter en soi, dans sa matérialité même, quelque chose quilui soit « autre »?? . Assim, do fio das formulações a serem analisadas, pinçaremos palavras, isoladas ou em grupo, que carregam os vestígios da memória discursiva da segregação, compartida por quem vive em Sorriso, tornando dizível e interpretável o que a enunciadora, assumindo a posiçãosujeito sulista, diz.

F1, a seguir, carreia o efeito de sentido de evitação do encontro com o outro no mesmo espaço, mediante emprego de formas que transpiram uma avaliação negativa, como "misturar muita gente" e "deixar todo mundo entrar":

F1: Nós era sócio do Lua Nova [clube de piscina] e a gente ia lá, depois começou a misturar muita gente, deixavam todo mundo entrar, aí eu não quis ir mais. E eu sou muito... sistemática.

\footnotetext{
${ }^{6}$ Doravante, abreviaremos o termo "formulação" pela letra $\mathbf{F}$.

7 Traduzido pelas autoras deste artigo a partir do original, citado no corpo do texto: "se considerarmos a sintaxe como um sistema neutro e fechado, como admitiremos que um texto pode portar em si, na sua própria materialidade, alguma coisa que lhe seja 'outra"” (SÉRIOT, 1986, p. 14).
} 
Em F1, usando o pretérito imperfeito, a enunciadora rememora uma prática de lazer da família - a prática de ir à piscina - interrompida pela percepção de que o clube já não era mais o mesmo, ou seja, relaxara no acesso dos frequentadores, permitindo a presença de hostis em meio aos socius. À medida que o Lua Nova deixa de ser um lugar exclusivo para os socius e libera a entrada para os hostis, permitindo "a entrada de todo mundo" e "a mistura de muita gente", ou seja, permitindo que socius e hostis nadem na mesma piscina, a enunciadora confessa ter desistido de ir ao clube, justificando sua atitude como sendo a de uma pessoa "muito... sistemática". Nesse caso, "ser sistemática" significa ser metódica, significa não tolerar a quebra da ordenação inicial que era a de só permitir a entrada dos socius, significa não tolerar a mistura de socius e hostis. A nomeação dos hostis por meio de expressões que designam coletividades, como "muita gente" e "todo mundo", significa depreciativamente aqueles que passam a frequentar o clube indiscriminadamente, sem qualquer seleção, a contragosto dos socius. Assim, ser "muito sistemática" significa a enunciadora não abrir mão, nem mesmo enquanto se diverte, do imperativo categórico - "Não se misture com os outros!" - imposto a si, como lema de vida. A enunciadora não se quer em hipótese alguma compartilhando o que julga ser seu território com os outros - os não-sulistas (nordestinos, nortistas, maranhenses). Em F1, já há indícios de como a divisão do corpo social urbano de Sorriso em "lado de cá" e "lado de lá" e o discurso da segregação que a permeia participam da formulação analisada, sinalizando o quão conflituosas são as relações entre as duas metades da cidade, mais e melhor dizendo, entre a população sulista e a população não-sulista.

O sentido de hostilidade em relação ao outro se avoluma à medida que a entrevista progride. O fato de o clube ficar do lado de "lá", tornando obrigatória a travessia daquela região da cidade, impõe à enunciadora a vivência de uma espécie de purgatório antes de chegar ao paraíso, como podemos ler em F2:

F2: Daí a gente, quando eu ia pro clube, eu me estressava antes de chegar no clube. [risos] Porque passa no meio desses bairrozinho pequeno aqui que tu vê de tudo. Dai era aquela criançada no meio da rua, pelada, de tudo que era jeito. Quando eu chegava lá em baixo, parecia que eu tinha que atravessar aquilo pra poder ter alguma coisa e ver toda aquela gente daquele jeito e eu chegava lá embaixo estressada. Eu não gostava mais de ir. Comecei a desgostar de ir só por ter que passar ali. Parecia que tinha que ter outra rua do outro lado pra passar. Ali tu via de tudo. Tinha uns bairrozinho, tem ainda... 
Em F2, ao falar da travessia que tinha de fazer para chegar ao Lua Nova, a entrevistada estranha, avalia negativamente e reprova o que vê nos bairros do lado de "lá". Ao se referir aos bairros que ficam no trajeto do clube, emprega o diminutivo (esses bairrozinho, uns bairrozinho), ao que parece, mais para apoucar e depreciar o lado de "lá" do que propriamente para se referir à dimensão do espaço, embora, na primeira ocorrência, "bairrozinho" venha acompanhado do atributo "pequeno". Aliás, o emprego do diminutivo para significar, não algo pequeno, mas o rebaixamento, a depreciação de algo, é bastante comum no uso do português em práticas discursivas que envolvem avaliação negativa do outro.

Quando ela diz à pesquisadora "aqui (nesses bairrozinho) tu vê de tudo" e "Ali tu via de tudo", muito provavelmente ela está se referindo a "tudo" como coisas reprováveis, coisas que seus olhos não gostavam de/queriam ver, como por exemplo: "aquela criançada no meio da rua, pelada, de tudo que era jeito". Neste trecho, o termo "criançada", em que o morfema "-ada" indica um coletivo de crianças, parece dialogar com uma memória discursiva que circula Brasil afora de que os pobres, principalmente os pobres nordestinos, geram muitos filhos, mais do que são capazes de sustentar e cuidar, por isso os abandonam à própria sorte. A falta de cuidados e o abandono são significados pelo predicativo "pelada" e pelo adjunto adverbial "no meio da rua", indiciando a negligência dos pais ao permitirem a exposição dos filhos a situações de risco e vulnerabilidade social. Crianças peladas brincando no meio da rua é uma cena pouco provável de ser vista do lado de "cá" de Sorriso, por isso narrada por uma voz que ressoa estupefação e repugnância. Pelo que e pelo como diz a enunciadora, o modo sulista de "criar filhos" provavelmente inclua vigilância constante das crianças pelo olhar do adulto, não permissão de brincadeiras no meio da rua e também cultivo de recato e pudor corporal desde a infância. Assim, "ver de tudo" é ver o que não se espera ver, é ver o que não se imagina ver, é ver o que se estranha, abomina e condena, enfim, é ver o avesso do que recomenda a moral e os costumes daqueles que falam, ocupando a posição-sujeito do colonizador sulista.

A visão de tal cena era tão desconfortável à entrevistada, que ela e sua família desistiram de frequentar o clube. Se, para desfrutar de alegres momentos de descanso e lazer em um espaço reservado, aconchegante, bem cuidado e entre os socius, o preço a pagar era ver o que viam na travessia obrigatória dos "bairrozinho", então não valia a pena ir ao clube. O mal-estar sentido pelo choque de hábitos culturais que o casal tinha de vivenciar no trajeto feito para o espaço-tempo do prazer materializa-se em formas 
como: "eu chegava lá embaixo estressada. Eu não gostava mais de ir. Comecei a desgostar de ir só por ter que passar ali.". Nesse enunciado, estressar-se, não gostar mais de e desgostar de são todos termos que indiciam a contrariedade e o aborrecimento da enunciadora ao ter de passar por ali para chegar ao Lua Nova. O adjunto adverbial $a l i$, nesse caso, não é apenas uma forma dêitica referencial que designa o lugar que está longe fisicamente da enunciadora, mas é um dêitico discursivo que significa o reduto da gente indesejável na Sorriso contemporânea, o reduto da gente que não se quer encontrar, com quem não se quer interagir nem de passagem e, muito menos, conviver.

F2 culmina com a enunciadora aventando a hipótese de outra rua de acesso ao clube, que passasse fora do perímetro dos "bairrozinho": "Parecia que tinha que ter outra rua do outro lado pra passar", de modo a evitar a visão do inferno. Nem o contato esporádico e fugaz da travessia era tolerado pela enunciadora que explicita a posição do casal e, possivelmente, de outros sócios do clube em relação ao "tudo" que eram obrigados a avistar no caminho. A repulsa pelo outro é tal que se chega a cogitar a existência de uma rua exclusiva para os socius passarem.

F2 parece ser muito mais a expressão de uma atitude de reprovação moral de hábitos destoantes daqueles da cultura gaúcha, tidos como os ideais, do que uma sensibilidade para a desigualdade social entre o lado de "cá" e o lado de "lá". E, se há uma sensibilidade para a desigualdade social, ela se manifesta, às avessas, por se impor à visão e não poder ser esquecida num momento em que se quer apenas desfrutar de um instante de lazer. Afinal, ser forçado a se deparar com a desigualdade e a ter consciência social é algo que se apresenta como um incômodo à diversão. O tempo da ludicidade e o tempo da consciência social parecem ser antitéticos. O gozo da ludicidade parece depender de uma anestesia da criticidade. Talvez, por isso, a enunciadora se mostre tão perturbada pela travessia obrigatória do lado de "lá", a ponto de desejar uma via alternativa para alcançar o clube. Porém, em F3, é possível perceber uma visão menos cínica e mais generosa no tocante à desigualdade social:

F3: Via aquelas crianças, tristeza de vida aquilo ali. Quando eu chegava lá em baixo, eu tava estressada de ver aquelas crianças, uma vida que a gente não quer pra gente.

As formas "tristeza de vida" e "uma vida que a gente não quer pra gente", em F3, produzem o sentido de que há uma certa consciência da desigualdade social. Se, em F2, o que contrariava a enunciadora era o modo de criação dos filhos destoante do modo gaúcho, em F3, o que parece incomodá-la é a pobreza, a privação em que vivem as 
crianças do lado de "lá". Para evitar o aborrecimento do encontro com o outro, quer por desaprovar o modo "licencioso" e negligente de criar os filhos, quer por não querer se deparar com a pobreza visível do lado de "lá", a entrevistada deixa até de frequentar o clube: "o que os olhos não veem, o coração não sente". Em F3, o "ali" é também um dêitico discursivo que significa o "lado de lá" como lugar de pobreza, da qual os do lado de "cá" se querem apartados para não terem de despertar de sua insensibilidade social.

Contudo, o lado de "lá" não é só o lugar de abandono das crianças, de carência, de pobreza e de tristeza; é também um lugar de muita festa e diversão, conforme F4:

F4: Se um dia você vir aqui eu vou te levar na sexta-feira. Ali você vê festa. Ali você vai ver festa. Meu Deus do Céu! Incrível de ver! Que nem formiga! Tu não pode andar de carro. E começa na sexta e vai até domingo. Se for lá agora tá fervendo. Divertido? Mas e muito! [...] E cada boteco tem festa, festa, festa... Dança no meio da rua, por tudo.

Se, em F1, F2 e F3, a enunciadora, assumindo a posição-sujeito sulista, reprova tudo o que vê do lado maranhense, em F4, surpreende-se com a intensidade das festas que acontecem "ali", a julgar pelo uso de expressões como "Meu Deus do Céu!", “Incrível de ver!". A ênfase na intensidade da diversão se expressa por meio da repetição da palavra "festa': "Ali você vê festa. Ali você vai ver festa.", "E cada boteco tem festa, festa, festa...”. Já, a ênfase na quantidade de pessoas que frequentam as festas prolongadas, que começam na sexta à noite e só terminam no domingo, se expressa metaforicamente mediante formas como: "Que nem formiga!" e "tá fervendo". É tanta gente que frequenta as festas que elas tomam conta da rua, a ponto de "não se poder andar de carro". São festas populares que se diferenciam muito das que ocorrem no lado de "cá" da cidade, geralmente em recintos fechados como clubes, danceterias, boates, casas de show, pubs nos quais se cobram entradas, mesas, camarotes, havendo, por consequência, uma seleção de público e também uma lógica diferente do que é concebido como festa.

Apesar de admitir que há muita animação, a entrevistada ressalta o perigo de frequentar as festas do lado de "lá", demarcando seu limite em relação à interação com aqueles que vivem além da BR163. Permite-se apenas passar de carro para espiar a festança de longe, pois a linha que separa a diversão da briga é muito tênue, conforme F5 e F6.

F5: Eu já passei umas duas, três vezes por que eu acho muito interessante aquilo ali. Passar de carro. Nunca desci, não tem como descer ali. Não, porque tem que levar a faca na bota. Talharam uma ontem de noite. Nove facadas ontem de noite. Enterraram ela hoje. 
F6: Ali é virado em boteco e música alto. É um lugar onde o povo... são muito divertido e tem muito boteco, som alto e a bebida... [...] $\mathrm{O}$ povo é bem divertido, só que onde tem muita bebida...

F5 e F6 evocam a memória discursiva de que os nordestinos são um "povo divertido", mas também dado à valentia, principalmente quando se excedem na bebida. Das tais festas é preciso manter distância, observá-las ao abrigo do carro. Evocando uma expressão tradicional do falar gaúcho: "tem que levar a faca na bota", a enunciadora lembra que ninguém se aventura a participar de uma das festas do lado de "lá", onde a bebedeira quase sempre desemboca na desordem e na violência, sem que esteja "armado", preparado para se defender de alguma investida. Na cidade, conta-se a anedota de que, na revista feita na portaria do clube, caso o frequentador esteja desarmado, uma arma é oferecida a ele para que possa se defender lá dentro. Para sustentar a tese de que o lado de 'lá' é um lugar de desordem, briga, criminalidade, a enunciadora apela para o argumento do exemplo, contando o "causo" de um assassinato brutal, provavelmente a facadas, a julgar pelo termo "talharam", ocorrido na noite anterior à entrevista

Em F6, a enunciadora ressalta a presença copiosa de botecos nos bairros situados no lado de 'lá' da BR 163, nos quais sempre há música alta, muita diversão, mas também consumo excessivo de bebida. E onde se consome muita bebida, a diversão e a confusão estão muito próximas, como sugere a afirmação "O povo é bem divertido, só que onde tem muita bebida...”. A enunciadora concorda com o fato de que o povo nordestino é animado, festeiro, o que é algo atrativo para quem está de fora da festa, contudo, o emprego da expressão "só que" permite antever que, apesar da diversão, não convém participar da folia porque tumultos e brigas são inevitáveis. O complemento da oração "só que onde tem muita bebida..." é suspenso por meio do emprego de reticências, supondo que ele já seja do conhecimento do enunciatário. Faz parte de nossa memória discursiva que onde há muita bebida, há também confusão, briga, violência e atrocidades. Assim, as reticências são imediatamente preenchidas pelo enunciatário. Destarte, em F5 e F6, o "ali" é o lugar da gente nordestina (maranhense), gente muito divertida e amante de festas, mas também muito impulsiva, colérica e valente quando se embebeda. O "ali" é um lugar de excessos, desregramento e intemperança, onde tudo acontece em proporções desmesuradas: muita festa, muita diversão, muito boteco, muita gente, música alta, muita bebida e muita confusão. 
O dissabor que a entrevistada sente ao ter de atravessar o bairro para chegar ao clube que frequentava, assim como a mistura de admiração e assombro com as festas (espiadas de dentro do carro em movimento) que tomam conta das ruas de sexta a domingo culminam com F7, que vincula tudo ao fato de o povo de lá ser "mais nordestino":

F7: O povo desse lado ali é o povo mais nordestino. A maioria é nordestino.

É incrível de ver, quando eu passo ali, nem parece que a gente tá em Sorriso.

Em F7 vigora o discurso presente em outros enunciados analisados de que os pioneiros construíram Sorriso nos moldes de cidades do Sul e fizeram dela uma extensão do Sul. Por isso, tudo que se apresente diferente disso lhes soa estranho. Afinal, "narciso acha feio o que não é espelho", como lemos em um dos versos de Caetano Veloso ${ }^{8}$. Quando os entrevistados relatam que, ao passarem do lado habitado pelos nordestinos, têm a impressão de não estarem em Sorriso, eles trazem à tona a memória discursiva de que o que caracteriza Sorriso como cidade é ter a "cara" do sul, ou seja, a cara do povo e da cultura do sul. Assim, assumido a posição-sujeito sulista, a entrevistada renega toda forma de vida que não reitere o modelo transplantado do Sul para o lado de "cá" de Sorriso pelos colonizadores. Ao dizer "quando eu passo ali, nem parece que a gente tá em Sorriso", a enunciadora significa o estar em Sorriso como estar em uma cidade do Sul, e o que difere disso torna-se estranho e inaceitável. O lado de "cá" é Sorriso; o lado de "lá" não é Sorriso. Trata-se também de um funcionamento discursivo dos dêiticos "cá" e "lá".

\section{Considerações finais}

Sorriso é uma cidade dividida em lado de "cá" e lado de "lá" pela BR163, uma rodovia que funciona como uma espécie de barreira étnico-social. Entre os dois lados não há isotopia. Quem está no lado de "cá” não se quer misturado com quem está no lado de "lá", por isso, procura evitar qualquer forma de encontro, até mesmo a simples travessia pelo bairro; procura manter-se afastado/aparthado ${ }^{9}$ da turba descomedida e libidinosa que vive do lado de "lá". O lado de "lá", ao menos no que diz respeito aos hábitos e modo de vida, quando interpretado por alguém que ocupa a posição-sujeito

\footnotetext{
${ }^{8}$ Letra da música "Sampa": Disponível em: http://www.vagalume.com.br/caetano-veloso/sampa.html. Acesso em 15/01/ 2016.

${ }^{9}$ Usamos essa grafia para evocar a palavra apartheid.
} 
sulista, como a entrevistada cuja rede de formulações é analisada neste artigo, é pura heterotopia. É o lado maldito da cidade. A vida dionisíaca, imoderada, orgiástica, ociosa, improdutiva, concentrada na fruição do presente e do carpe diem, desordenada ou permeada por uma ordem confusional (MAFFESOLI, 1985, p.16) vivida do lado de "lá" contrasta com a vida apolínea, moderada, produtiva, voltada para o futuro triunfante, racionalizada e organizada segundo a lógica do trabalho e do progresso vivida do lado de "cá". Esses modos de vida são como água e óleo, não se misturam. O ser-junto-com que tipifica a vida vivida do lado de "lá" é incisivamente repelido pela moral do dever-ser que orienta a vida vivida do lado de "cá".

Semanticamente, o estranhamento e a reprovação do ser-junto-com pela moral do dever-ser, encarnada por uma enunciadora que se expressa rente à posição-sujeito sulista, se materializam em formas linguísticas como: "criançada no meio da rua, pelada, de tudo que era jeito"; "ver toda aquela gente daquele jeito"; "Que nem formiga!”; "Tu não pode andar de carro"; "Se for lá agora tá fervendo", nas quais o sentido da proeminência e efervescência do corpo coletivo em que o outro se dissolve ganha destaque.

Discursivamente, a enunciadora funciona como um "bom sujeito", já que, como sujeito particular, se identifica plenamente com o Sujeito Universal da formação discursiva determinada pelo interdiscurso. De acordo com Pêcheux ([1975] 1988, p. 215), o "bom sujeito" é a modalidade de funcionamento discursivo em que há um recobrimento total entre o enunciador e o Sujeito (Sujeito Universal da formação discursiva e ideológica), "um assujeitamento na forma do "livremente consentido"". O bom sujeito "reflete espontaneamente o Sujeito"; "realiza seus efeitos "em plena liberdade"”. Em momento algum a entrevistada se aparta do discurso dominante que naturaliza a divisão física e social de Sorriso. Suas formulações legitimam, sem desconfiança e sem qualquer gesto de dissensão da formação discursiva que a determina, enunciados que põem em circulação os sentidos da divisão, hierarquização, discriminação e segregação.

Se os discursos constituem uma forma de existência prática das ideologias engendradas em determinado momento da história de uma formação social, então nos interrogamos sobre a formação ideológica que determina a produção e circulação de um discurso segregacionista em meio à população sorrisense. Perguntamo-nos: a enunciadora, cujas formulações reafirmam o discurso segregacionista, fala interpelada por qual formação ideológica? O modo como ela significa o outro que vive na mesma 
cidade em que ela vive parece identificá-la à posição-sujeito característica da ideologia da colonização que se implantou naquela formação social desde que os migrantes do sul aportaram na região do médio norte de Mato Grosso, na década de 1970, movidos pelo propósito de expandir a fronteira agrícola e povoar uma parte do país, tida pelo regime militar, como um imenso vazio populacional, uma vez que os povos indígenas e os grileiros que ali viviam não contavam entre os brasileiros com direito a terra. Era como se não existissem, como se não fossem gente.

Retomemos, como ponto de partida, a pesquisa etimológica que Alfred no Bosi (1992, p. 11-64) realiza sobre a palavra "colonização". Segundo o autor, as palavras cultura, culto e colonização se originam do verbo latino colo que significava eu moro, eu ocupo a terra, e, também, eu trabalho, eu cultivo o campo. Essa forma latina arcaica está presente na palavra portuguesa íncola que significa "o próprio habitante da terra" e também na palavra agrícola que se refere ao "trabalho no campo". Transformada, a forma colo está presente na palavra inquilino, significando aquele que reside em terra alheia. Já a palavra cultura viria da forma culturus (particípio futuro de colo) e culto, da forma cultus (particípio passado de colo) ${ }^{10}$. A forma colo está presente também nas palavras colônia, colono e colonizar: colônia (espaço que se ocupa e terra ou povo que se pode trabalhar e sujeitar), colono (aquele que cultiva uma propriedade rural e vem se estabelecer no lugar do íncola) e colonizar (ocupar, povoar e cultivar a terra de modo a fazê-la produzir riquezas). Assim, a forma colo significa tanto eu moro quanto eu cultivo.

Pergunta-se Bosi (1992, p. 12): “o que diferencia habitar (colônia) e cultivar (colono) de colonizar?”. Responde o autor: é “o deslocamento que os agentes sociais fazem de seu mundo (onde vivem como íncola) para outro onde irão exercer a capacidade de lavrar ou fazer lavrar o solo alheio (onde se tornarão colonos)". Em princípio, o colono não é dono da terra, é apenas aquele que a trabalha. Porém, “a produção dos meios de vida e as relações de poder, a esfera econômica e a esfera política, reproduzem-se e potenciam-se toda vez que se põe em marcha um ciclo de colonização" (BOSI, 1992, p. 12). Essa relação entre uma esfera e outra potencializa o poder daqueles que se imbuem do papel de conquistadores/desbravadores que correm risco e se sacrificam na empresa da colonização. Sobre isso afirma Bosi (1992):

\footnotetext{
${ }^{10}$ Nesta conclusão, vai-se retomar apenas a família semântica nucleada pela forma colo que inclui palavras como colonização, colonizar, colônia, colono etc.
} 
[...] a dominação é inerente às diversas formas de colonizar e, quase sempre, as sobredetermina. Tomar conta de, sentido básico de colo, importa não só em cuidar, mas também em mandar. Nem sempre, é verdade, o colonizador se verá a si mesmo como a um simples conquistador; então buscará passar aos descendentes a imagem do descobridor e do povoador, títulos a que, enquanto pioneiro, faria jus. (BOSI, 1992, p. 12)

Ainda conforme Bosi (1992, p. 15), “a colonização é um projeto totalizante cujas forças motrizes poderão sempre buscar-se no nível do colo: ocupar um novo chão, explorar os seus bens, submeter seus naturais". O processo de colonização não se constrange em recorrer a métodos cruéis para ocupar o novo chão e fazer dele seu domínio. A história do Brasil é abundante em exemplos de extermínio ou escravidão dos íncolas que aqui viviam desde o início da colonização. De acordo com Gilberto Freire (apud BOSI, 1992, p. 22), "o açúcar eliminou o índio". E, no projeto expansionista das décadas de 1970 e 1980, “o gado expulsa o posseiro; a soja, o sitiante; a cana, o morador" (BOSI, 1992, p. 22). Na história de formação de Sorriso, isso não foi diferente, já que os compradores de terra vindos do Sul exigiam que a terra estivesse "limpa", quer dizer, sem gente em cima, sem grileiros, sem íncolas.

No lugar dos antigos íncolas, despejados de seu chão, uma nova população de íncolas aí se formaria - os primeiros migrantes sulistas, os pioneiros, que viriam na condição de colonizadores não apenas para morar e cultivar a terra, mas também para mandar, afinal a produtividade econômica nos moldes capitalistas demanda o domínio do homem sobre a natureza e sobre os outros homens. Domínio econômico (domínio dos meios de produção) e domínio político (domínio sobre as pessoas) andam de mãos dadas. Quem chegou depois à região, e não como colonizador, estava predestinado a ocupar o lugar de um inquilino incômodo; esses seriam os nordestinos/maranhenses, enfim, os não-sulistas. Como afirma Bosi (1992, p. 62), “o olho do colonizador não perdoou, ou mal tolerou, a constituição do diferente e sua sobrevivência. [...] Sempre uma cultura vale-se de sua posição dominante para julgar a cultura do outro”. A forma como a entrevistada, cujas formulações são analisadas neste estudo, significa o que vê do "lado de lá" é a expressão da malquerença do colonizador em relação aos outros que, passada a fase dura do desbravamento, vieram/vêm se instalar em/desfrutar da cidade já formada como estranhos e oportunistas, ou seja, como hostis. O tempo da colonização pode ter passado, mas a ideologia da colonização que se materializa no discurso segregacionista continua muito viva na formação social de Sorriso. 
Destarte, a formação da "sorrisidade" é vista como inteiramente tributária da herança sulista, silenciando a participação do outro nordestino/maranhense. Ao invés da cara sulista/gaúcha, a "sorrisidade" poderia apresentar uma cara híbrida sulistanordestina ou gaúcha-maranhense. E a BR163 poderia ser a "ponte" que liga os dois lados da cidade e une as gentes, quaisquer que sejam, que formam o corpo social urbano de Sorriso, e não o "muro" a simbolizar o apartheid entre quem vive do lado de "cá" e quem vive do lado de "lá". Ao invés de barreira a confinar cada um a viver em seu lado, a BR163 poderia ser o canal de comunicação e ligação entre os dois mundos, expandindo os espaços de interação e sociabilidade entre diferentes que vivem em Sorriso.

Que este estudo possa funcionar como uma tomada de consciência do passado e do presente de Sorriso como uma sociedade dividida, encetando gestos favoráveis a uma reunião das duas metades ideológica e historicamente separadas. Vemos, como Bosi (1992, p. 17), "a crítica do senso comum e a consciência da historicidade da própria visão de mundo como pré-requisitos de uma nova ordem cultural”. Que essa nova ordem cultural e social não demore a acontecer, com os dois lados da cidade costurando as diferenças numa "sorrisidade mestiça". Afinal, o discurso da colonização, segundo o qual todos sabem, veem, dizem, compreendem que o lado de "lá" é o lado maldito, é apenas uma construção histórica e tudo o que é histórico retém a incompletude que incomoda e torna a mudança desejável e possível...

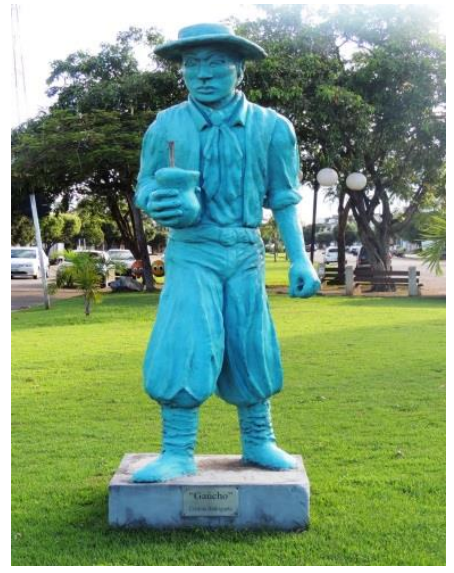

Lado de cá: "Gaúcho". Escultura situada no canteiro central da Av. Blumenau.

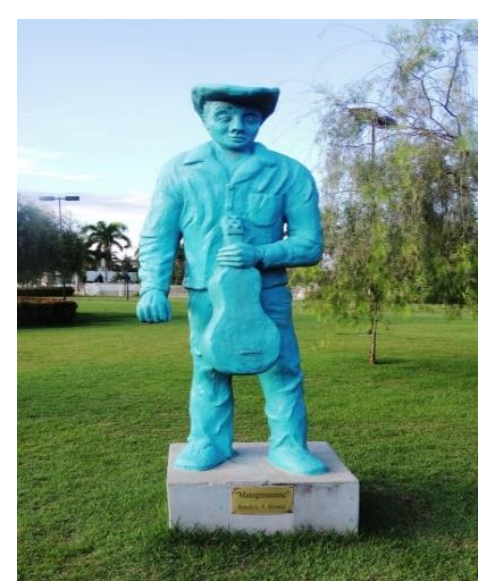

Lado de cá: "Mato-grossense". Escultura situada na Praça das Fontes.

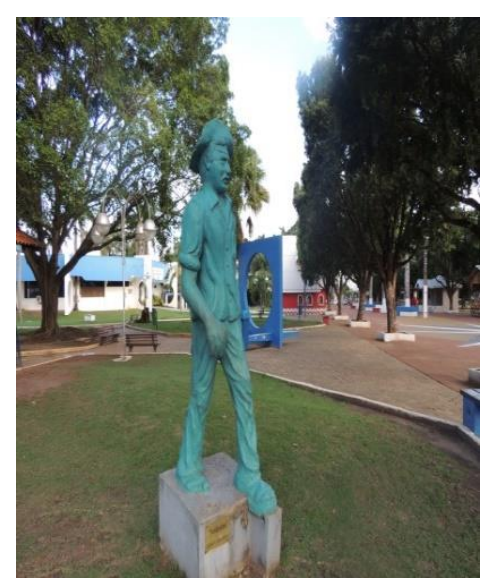

Lado de cá: "Nordestino". Escultura situada na Praça da Juventude. 


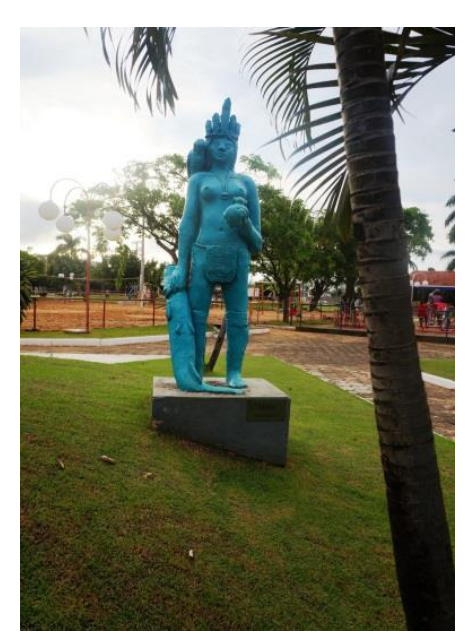

Lado de cá: "Índia". Escultura situada na praça da Prefeitura.

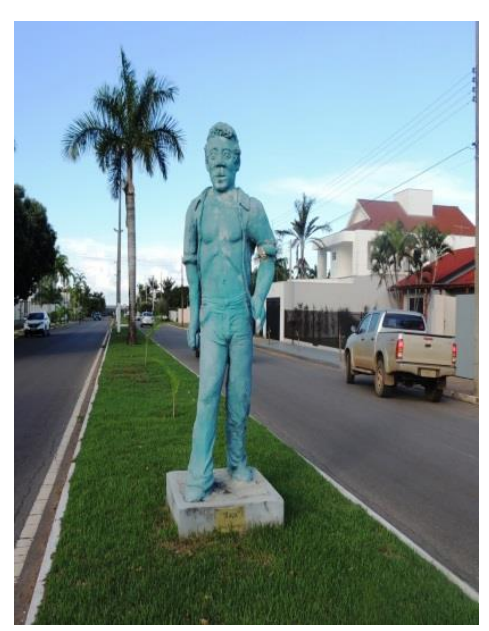

Lado de cá: "Raça". Escultura situada na Av. dos Imigrantes.

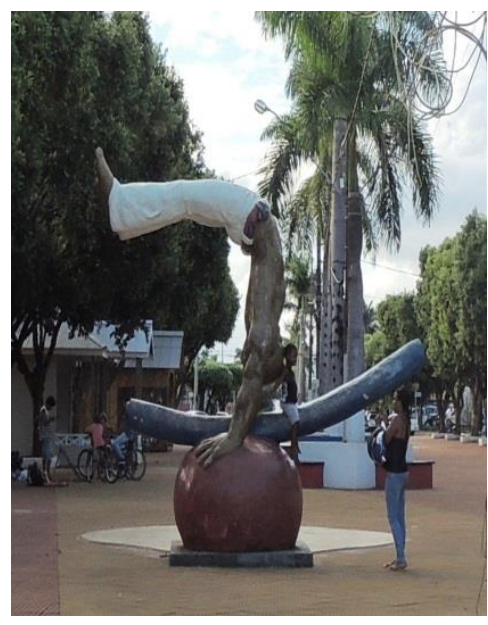

Lado de cá: "Capoeirista". Escultura no centro da Praça da Juventude.

Imagem: Estátuas exibidas em locais públicos do lado de cá de Sorriso-MT.

Fonte: Acervo fotográfico das autoras.

\section{Referências}

ALMEIDA, Luciana Schleder. Gaúchos, festas e negócios: o agronegócio da soja no Meio-norte Matogrossense. 2013, 205p. Tese (Doutorado em Ciências Humanas Antropologia Cultural). Instituto de Filosofia e Ciências Sociais, Universidade Federal do Rio de Janeiro, Rio de Janeiro, RJ, 2013.

ALMEIDA, Terezinha Ferreira de. A BR 163 no município de Sorriso: apartheid do corpo social urbano, 2016, 149p. Dissertação (Programa de Pós-Graduação em Estudos de Linguagem). Instituto de Linguagens, Universidade Federal de Mato Grosso, Cuiabá, MT, 2016.

BOSI, Alfredo. Dialética da colonização. São Paulo: Cia das Letras, 1992.

ALTHUSSER, L. Aparelhos Ideológicos de Estado. Rio de Janeiro: Graal, [1970] 1985.

COURTINE, Jean-Jacques. Análise do discurso político: o discurso comunista endereçado aos cristãos. São Paulo: EdUFSCAR, [1984] 2009.

COX, M. I. P. “JE est um mot d'ordre": escritos em torno de sujeito, linguagem e educação. 1989, 264p. Tese (Doutorado em Educação). Instituto de Educação, Universidade Estadual de Campinas-UNICAMP, Campinas, SP, 1989.

DUARTE, Cristovão Fernandes. Circulação e cidade: do movimento da forma à forma do movimento. 2002, p. 241p. Tese (doutorado). UFRJ/IPPUR, Rio de Janeiro, 2002.

FELMAN, S. La folie et la chose littéraire. Paris: Seuil, 1978.

FOUCAULT, Michel. Arqueologia do saber. Rio de Janeiro : Forense-Universitária, [1969] 1986.

LEFEBVRE, H. La production de l'espace. Paris: Anthropos, 2000.

A revolução urbana. Belo Horizonte: EdUFMG, [1970] 1999. 
MAFFESOLI, Michel. A sombra de Dionísio: contribuição a uma sociologia da orgia. Rio de Janeiro Graal, 1985.

MALDIDIER, Denise. A inquietação do discurso - (Re)ler Michel Pêcheux hoje. Campinas: Pontes, 2003.

MARTINS, Tereza Maria. Discurso e cidade: uma análise discursiva do bairro. 2012, 110 p. Tese (doutorado em Estudos Linguísticos). Programa de Pós-graduação em Estudos Linguísticos, Universidade Estadual Paulista Júlio de Mesquita Filho, São José do Rio Preto, SP, 2012.

ORLANDI, Eni Puccinelli. Discurso em análise: sujeito, sentido e ideologia. 2.ed. Campinas: Pontes, 2012. 2008.

Discurso e texto: formulação e circulação dos sentidos. Campinas: Pontes,

Cidade dos sentidos. Campinas: Pontes, 2004.

- Análise de Discurso: princípios e procedimentos. Campinas: Pontes, 1999.

Paráfrase e Polissemia. A fluidez nos Limites do Simbólico. RUA, Revista do

Núcleo de Desenvolvimento da Criatividade. Campinas, n. ${ }^{\circ}$ 4, março de 1998.

PÊCHEUX, M. Analyse automatique du discours. Paris: Dunod, 1969,

Semântica e discurso: uma crítica à afirmação do óbvio. 3. ed. Campinas: Editora da Unicamp, [1975] 1988.

RIMBAUD, Arthur. Oeuvres Complètes. Paris: Gallimard, 1972.

SÉRIOT, Patrick. Langue russe et discours politique soviétique: analyse des nominalisations. Langages. Analyse de discours, nouveaux parcours [Hommage à Michel Pêcheux], 21 ªnnée, N81, p. 11-41 1986.

Data de Recebimento: 19/05/2016

Data de Aprovação: 31/08/2016 


\section{Para citar essa obra:}

ALMEIDA, T. F., COX, M. I. P. O lado nordestino da cidade de Sorriso: o lado maldito segundo a posição-sujeito sulista. In: RUA [online]. $n^{\circ} .22$. Volume 2, p. 493 - $524-$ ISSN 1413-2109/2179-9911 - Novembro/2016. Consultada no Portal Labeurb - Revista do Laboratório de Estudos Urbanos do Núcleo de Desenvolvimento da Criatividade. http://www.labeurb.unicamp.br/rua/

Capa: Estátuas exibidas em locais públicos do lado de cá de Sorriso-MT. Fonte: Acervo fotográfico das autoras.

\section{Laboratório de Estudos Urbanos - LABEURB}

Núcleo de Desenvolvimento da Criatividade - NUDECRI

Universidade Estadual de Campinas - UNICAMP

http://www.labeurb.unicamp.br/

\section{Endereço:}

LABEURB - LABORATÓRIO DE ESTUDOS URBANOS

UNICAMP/COCEN / NUDECRI

CAIXA POSTAL 6166

Campinas/SP - Brasil

CEP 13083-892

Fone/ Fax: (19) 3521-7900

Contato: http://www.labeurb.unicamp.br/contato 